UDC 574.42

DOI: $10.15587 / 2519-8025.2018 .141170$

\title{
PHYTOINDICATORS OF ECOSYSTEM DYNAMICS IN RING-BANK UKRAINIAN POLISSIA
}

\author{
(C) I. Khomiak, I. Onishchuk, N. Demchuk
}

У публікації аналізуються результати досліджень динаміки енергетичних характеристик екосистем. Метою роботи є на основі показників кількості надземної фітомаси, ї̈ віку та зміни флористичного складу, продемонструвати можливість фітоіндикаційної оцінки динаміки екосистем, визначити як показники надземної фітомаси закономірно зростають під час саморозвитку природних екосистем (автогенної сукиесії).

Матеріали і методи. Надземна фітомаса вимірялася в екосистемах, шуо знаходяться на різних стадіях автогенної сукцесії. Для урівноваження коливання показників, викликаних домінуванням видів із різним типом фотосинтезу, використано поправку на вік наземної фітомаси.

Результати. Показник динаміки закономірно зростає під час автогенної сукиесії. Зовнішні впливи відхиляють його від основного тренду. Антропогенний вплив часто зміщує сукиесію в протилежному напрямі. Метод апробовано на території Правобережного Полісся в Украӥні. Розширення бази даних результатів визначення показника динаміки дозволяє визначати цеей показник із достатньою для практичних $i$ теоретичних иілей точністю. Цей метод дає можливість проводити дослідження термодинаміки (запасів енергї й ентропії) та динаміки екосистем безконтактним способом без впливу на біорізноманіття рослин. Він є найбільш прийнятним для таких досліджень в межах природно-заповідних територій. В межах таких об’єктів не дозволяється вилучати надземну фітомасу, для визначення енергетичних $i$ динамічних показників.

Висновки. Показник динаміки, щзо відповідає положенню на лінії автогенної сукцесії, залежить від фітомаси та ї̈ віку. Значення ентропії екосистеми буде обернено пропориійне показнику ї̈ динаміки. Цей показник може бути визначеним з використанням фітоіндикаційних методик. При цьому похибка вимірювання коливатиметься в діапазоні $3 \%-10 \%$. Ми можемо ие використовувати під час планування роботи в заповідниках, на рекультивованих землях, в лісовому господарстві тощо. Обраний метод дає високий економічний ефект та створює можливості покращення відносини людини із довкіллям

Ключові слова: екосистема, динаміка, фітомаса, фітоіндикація, сукцесія, енергія, ентропія, показник динаміки, саморозвиток

\section{Introduction}

At the present stage ecological science is finishing its transition from descriptive methods to more complex system approach $[1,2]$. In order to accomplish this objective it is necessary to create realistic models of the ecosystem dynamics and energy cycling $[3,4]$. Because ecosystems are very complex objects consisting of a vast set of elements affected by many factors, the final determination of their thermodynamic properties can be regarded as a difficult theoretical and practical problem [5]. However, without achieving this goal further progress in ecology is impossible [4].

\section{Literature review}

Integrating biospherological ideas of Vernadsky, ecosystem approaches of E. Odum and classical laws of thermodynamics, we can conclude that ecosystems tend to decrease the entropy level in the process of their selfdevelopment $[2,6]$. However, we do not see entropy in ecosystems similar to its definition in the second law of thermodynamics [7, 8]. Since above-organism organization levels are higher units of nature, their individual properties gain new emergent content. [9, 10]. For ecosystems we define entropy as a measure of indeterminacy or randomness of energy that has entered from outside the system, and some of which has dispersed and lost [7, 11]. The biomass energy accumulated by autotrophic organisms and exiting directly or indirectly the ecosystem could be an example of such indices $[12,13]$. Energy stored in the ecosystem and the time during which it is held, can be a reliable indicator of entropy and characteristics of the current ecosystem development phase [15, 16].

It should be noted that the direct biomass assessment methods are rather costly, inconvenient and in some cases (protected areas or presence of endangered species) unacceptable, while existing contactless remote methods can be inaccurate, giving significant measuring errors [17]. Today, the search for convenient noncontact approach to determining the level of ecosystem entropy is very crucial $[18,19]$. As the composition of natural vegetation changes characteristically during the ecosystem self-development, the use of indirect phytoindication methods is very promising $[20,21]$.

\section{The aim and objectives of the study}

The goal of the study is to search for objective parameters to determine the indicator of the ecosystem dynamics. been set:

To accomplish the aim, the following tasks have

1. Reveal the dependence of above-ground phytomass with indicator of the ecosystem dynamics.

2. To explain the energy changes in ecosystems from the standpoint second law of thermodynamics

3. Set the ability to use phytoindication for setting the indicator of the ecosystem dynamics. 
4. Determine the application scope of the phytoindication dynamics indicator.

\section{Materials and methods}

Research materials are represented by the standard phytosociological relevés made at 8 stationary polygons and 1052 relevés obtained from expeditions using route-based assessment method on the territory of RightBank Polesie [22]. Polygons were divided into 10 equable plots. The aboveground phytomass from one of the research plots was sampled for weighting. Also field measurements of ground phytomass amount were carried out directly on the stationary polygons [18]. Additionally forest inventory materials were used kindly furnished by Bilokorovychi forestry.

In order to analyze the environmental conditions we used phytoindication methods. Phytosociological relevés were processed using Simargl 1.12 software package [23]. Environmental factor indices were measured in points according to the uniform phytoindication scale, developed by Ya. Didukh and P. Plyuta [21]. Using mentioned above phytoindication approach we have selected polygons with similar initial conditions.

\section{Results and discussion}

In all investigated plots yearly increase of aboveground phytomass was observed (Fig. 1). However, there are certain reasons why this attribute cannot serve as a universal indicator of dynamics. Since the first plant communities were formed mainly by therophytes, the phytomass was decomposing mainly during the offseason. Thus, the first three years after the termination of soil tilling, the energy in the ecosystem was not accumulating. The increase in aboveground phytomass amount was due to the increased productivity. The productivity changes were, in turn, due to the increase in segetal species projective cover and also due to the plot colonization by more productive populations of ruderal species. Such changes cannot give information about reducing of the ecosystem entropy, and therefore cannot serve as development indicators. Some researchers have mentioned cases of a slight phytomass reduction in the process of phytosystem self-development [20]. This happens during the displacement of tall ruderal species by meadow species, along with the replacement of dominant species in renewable young forests (Betula pendula Roth., Populus tremula L. Salix caprea L.) by the characteristic species of primary and subclimax woodlands (Quercus robur L., Carpinus betulus L., Acer platanoides L. ). Phytomass reduction in the early stages of secondary succession is described by A. A. Titlyanova with coauthors [20].

We have observed similar phenomena for the forest succession stage in the Central Polesie. The loss of the dominant Betula pendula for a short time has led to phytomass decrease in different plots from 232 t/ha to $194 \mathrm{t} / \mathrm{ha}$; from $237,7 \mathrm{t} / \mathrm{ha}$ to $210,9 \mathrm{t} / \mathrm{ha}$; and from $205 \mathrm{t} / \mathrm{ha}$ to $194.3 \mathrm{t} /$ ha respectively. Quercus robur, represented in the second tree layer, was not able to recover quickly from this loss due to the low growth rate.

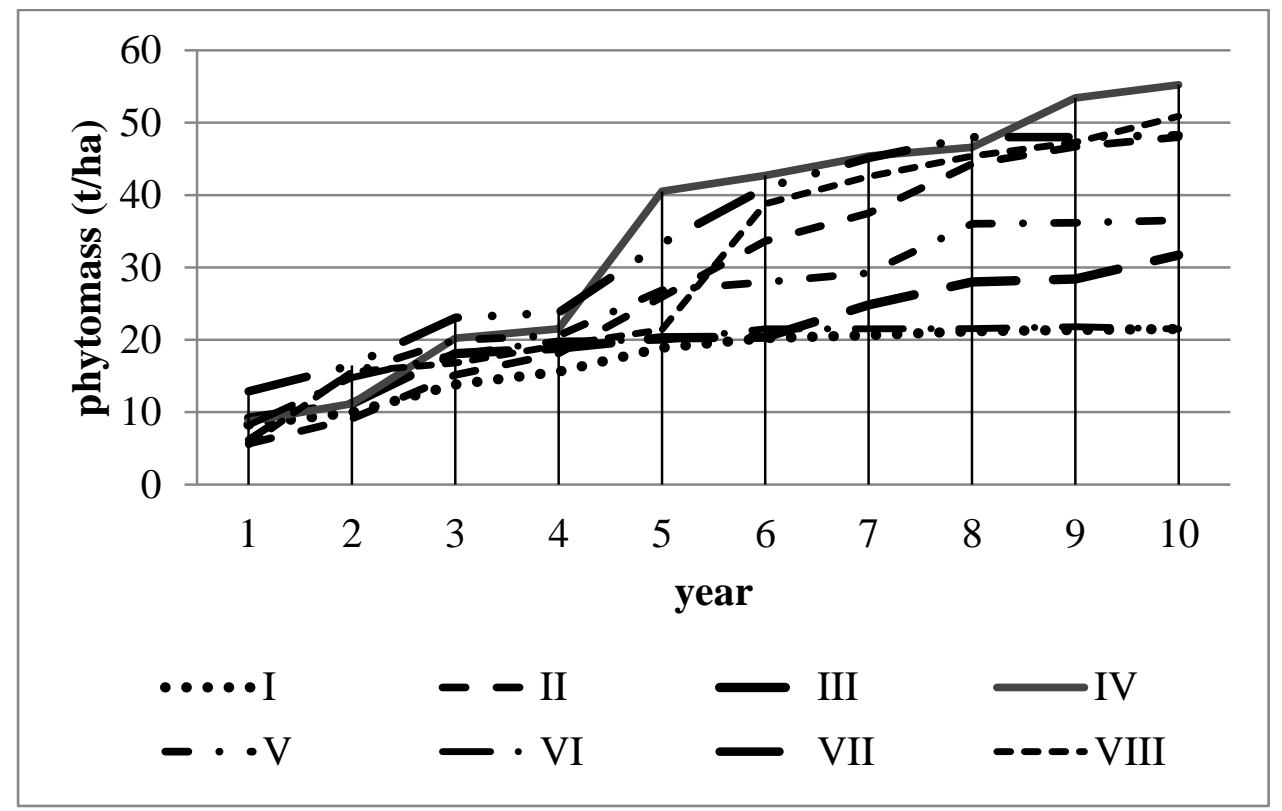

Fig. 1. Phytomass change rates (t/ha) over time (years). I-VIII - stationary polygons.

Another important indicator is the rate of phytomass buildup, which combines the productivity increase and perennials phytomass accumulation (Fig. 2). In all studied polygons and plots growth rates were different due to internal and external factors. Among the external factors there are various anthropogenic impacts, seed dispersal from the other neighboring habitats, zootic and microclimatic fac- tors. Some changes in phytomass buildup are synchronized. They are caused by internal factors structural rearrangements of plant communities, changes of dominant species and their life forms. These changes are associated with the decrease in annuals dominance and formation of stable meadow communities involving biennials and phanerophyte layer formation. 


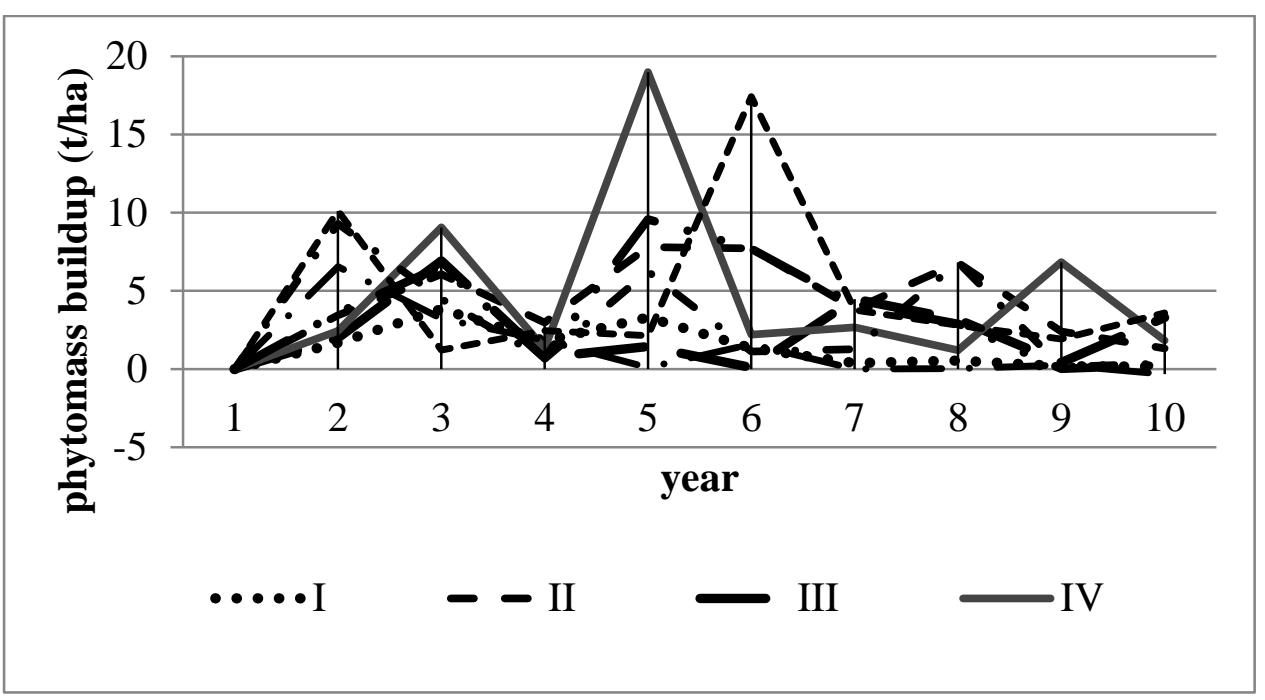

Fig. 2. The indices of phytomass buildup rates (t/ha). I-VIII - stationary polygons.

Considering that for the reduction of ecosystem dissipated energy not only its gross rate is important, but also the ability to retain energy for a long period of time, we can use the following formula to determine the degree of ecosystem self-development:

$$
S_{t}=\frac{\Sigma T_{n} G_{n}}{k}
$$

where $S_{t}$ - index of ecosystem self-development (position within the sequence of autogenic succession), $T_{n}$ - number of vegetative seasons since the time of phytomass formation, $G_{n}$ - volume of living aboveground phytomass (t/ha), $k$ - score conversion coefficient. In order to convert our results into phytoindication points we used the flatland area of Poyaskivskiy Forest as a standard. This grove is the oldest and best preserved on the territory of Polesie (the wood procurement and other intensive forestry management on its territory was stopped more than 150 years ago) The forest had a top quality shipbuilding timber resources; and became protected in 1926 for the detailed model studies of natural forest development without human impact. We have created a 21-point scale, where the highest score was attributed to parameters of the plot mentioned above, and " 0 " was attributed to the territory with little to no vegetation. This index best represents the thermodynamics of ecosystem self-development. It gives good results in all investigated succession series (Fig. 3).

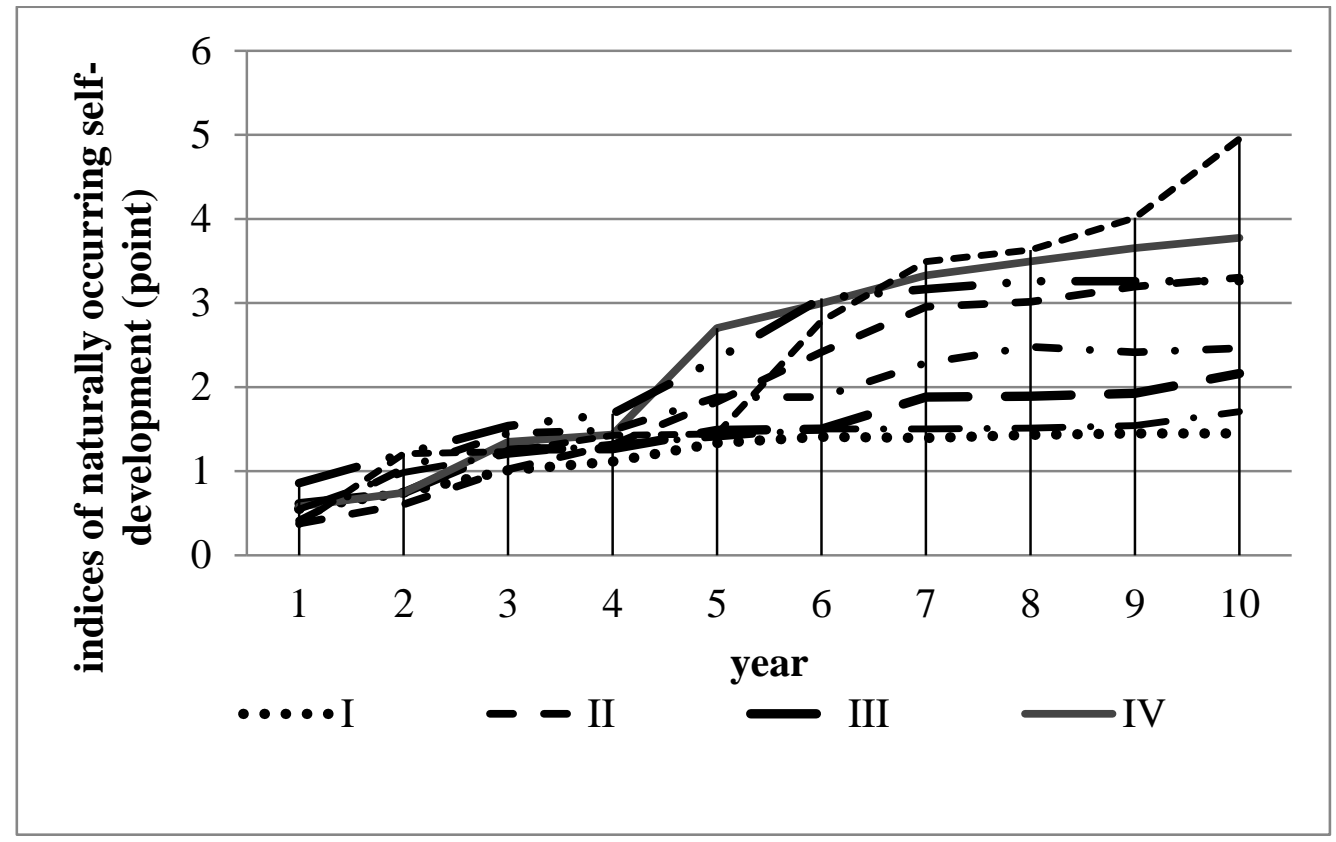

Fig. 3. The indices of naturally occurring self-development of ecosystems (point). I-VIII - stationary polygons

In our experiment, indices from different sites differed insignificantly during the first four years $\left(\sigma^{2}\right.$ ranged from 0.04 to 0.22 ) (Fig. 4). Since the seventh year of the study, the dispersion ranges from 0.93 to 1.37 . The rea- sons for such dispersion growth cannot be edaphic and microclimatic conditions in the studied areas. The initial conditions were very similar. For edaphic factors starting indices varied within the range of $5.2 \%$ on average and 
the maximum deviation for carbonate content was $6.1 \%$. Microclimatic conditions indices varied $5.2 \%$ on average and a maximum deviation was $9.63 \%$ for ombroregime $(\mathrm{Om})$ factor. The anthropogenic factor values (degree of anthropogenic transformation) deviated $2.22 \%$ on average and a maximum recorded deviation was $2.85 \%$. Such deviations are within the measurement error for segetal ecosystems. Dispersion ranged from $\sigma^{2}=0,035$ to $\sigma^{2}=0,2918$ with the mean value of $\sigma^{2}=0,766$.
The most important reason for such variation of parameters is the anthropogenic factor. It is considered that most of the anthropogenic pressure returns the ecosystems to their earlier development stages. Our study confirms the high inverse dependence between selfdevelopment ecosystem indices and the stage of ecosystem anthropogenic transformation (Fig. 5). The correlation and reliability approximation coefficients amount to 0.91 and 0.83 respectively.

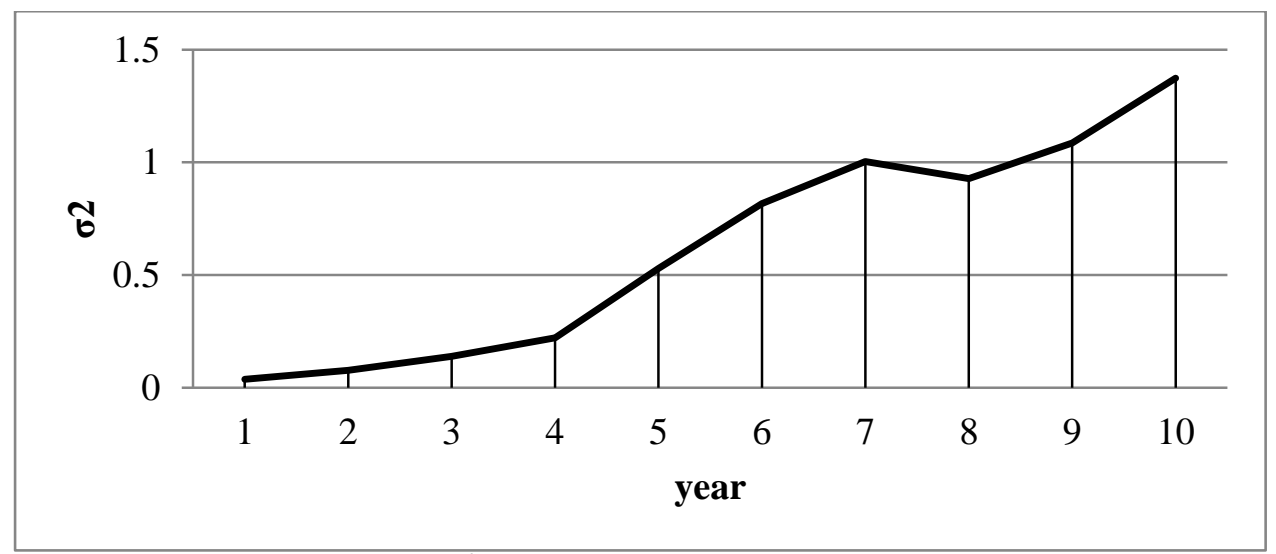

Fig. 4. Dispersion values $\left(\sigma^{2}\right)$ for the natural ecosystem self-development indices

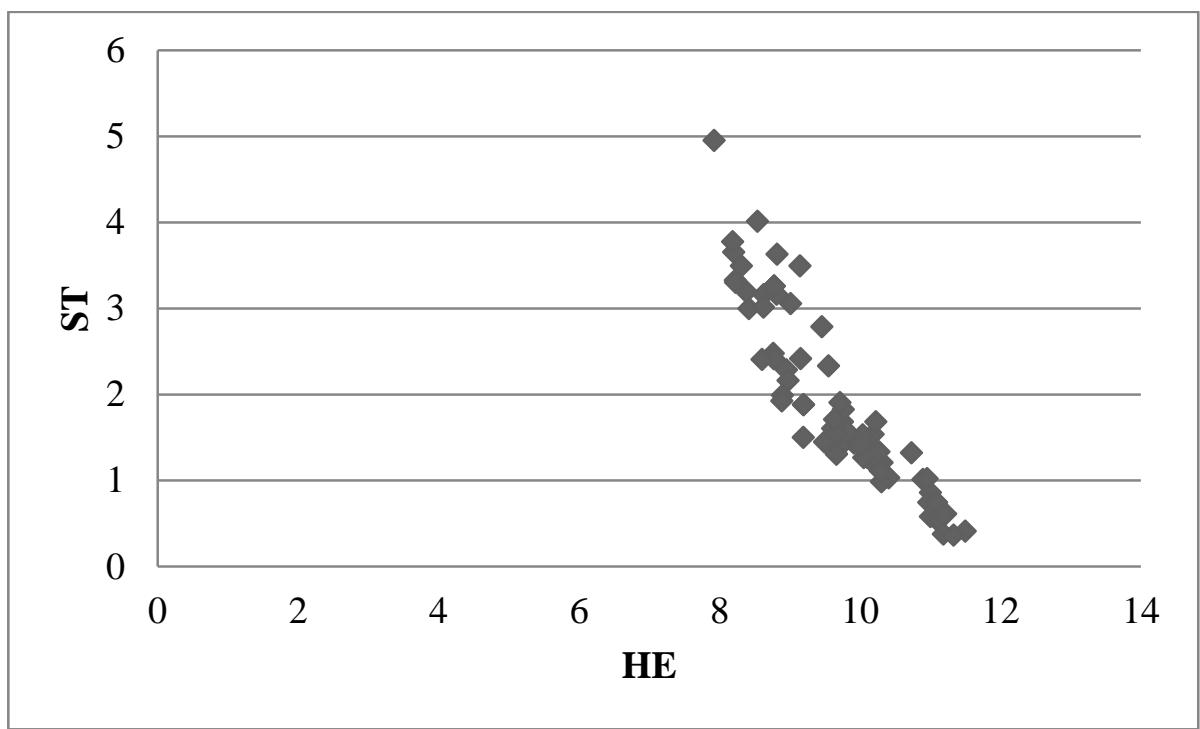

Fig. 5 The relationship between the indices of anthropogenic transformation degree (HE) and the stage of natural ecosystem self-development (ST) (point)

The analysis of species occurrence along the sequence of succession stages allows transition from the direct (instrumental) measurements ecosystem dynamics towards the indirect phytoindication approach. Plant species always conform to the certain parameters of ecosystem self-development. The distribution of species' projective covers along the phytoindication scales show classic patterns, described by the optimum law and Shelford's Law of Tolerance (Fig. 6, 7). 


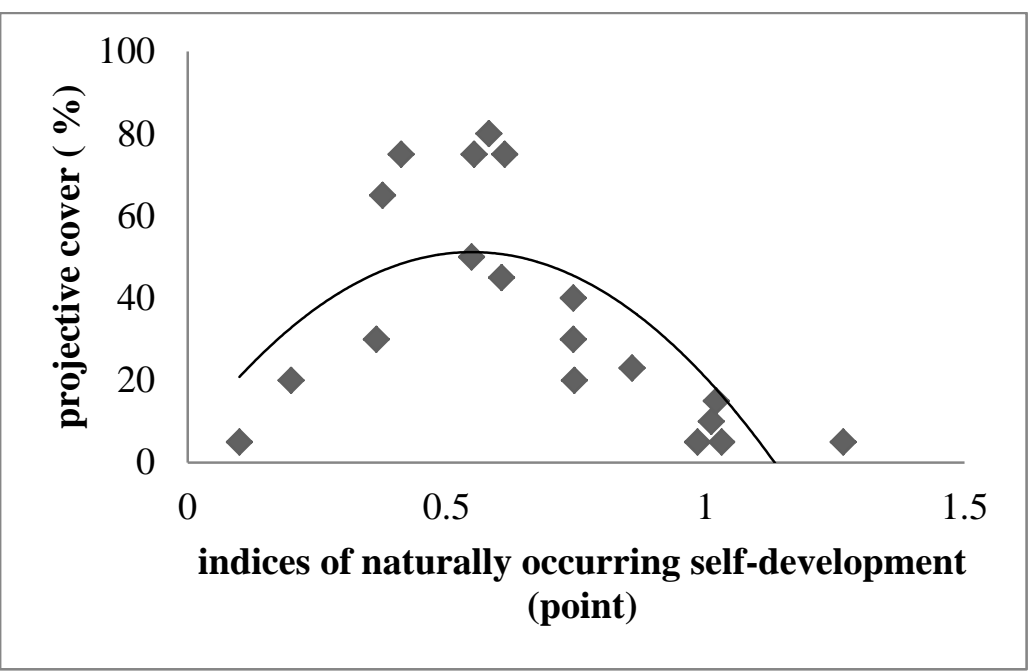

Fig. 6. Indices of natural ecosystem self-development stage for Echinochloa crusgalli



Fig. 7. Indices of natural ecosystem self-development stage for Poa prantense

This allows using classical phytoindication techniques. To this end, we have created a database of more than 700 plant species, with defined indices of dynamics. Further, this database was extended by calculating indices, based on phytosociological relevés, where data on most species have previously been imported. The measurement error, associated with phytoindication method, ranges from $3 \%$ to $10 \%$ depending on the number of species in the relevé and their availability in the main database. These values commensurate with the accuracy of data, obtained by direct measurements (5-10\%).

\section{Conclusion}

1. The unit that will correspond the selfdevelopment stage, is an index that is directly propor- tional to the aboveground phytomass quantity and its age.

2. The ecosystem entropy value will be inversely proportional to the self-development stage index.

3. This index can be determined by classical phytoindication methods upon detailed database availability. Measurement errors, associated with phytoindication method range from $3 \%$ to $10 \%$ comparing to 5-10\% for the direct method, are commensurate.

4. The phytoindication approach allows application of this methodology on the protected areas. The index of ecosystems self-development stage can be used to predict the development of specific studied plots and for the needs of ecosystem classification.

\section{References}

1. Didukh Ya. P. Etiudy fitoekolohiyi. Kyiv: Aristei, 2008. 268 p.

2. Odum Yu. Ekologiya. Vol. 1. Moscow: Mir, 1986. 327 p.

3. Kennedy I. R. Action in Ecosystems: Biothermodynamics for Sustainability. Baldock, Hertfordshire, England: Research Studies Press Ltd, 2001. 251 p.

4. Vernadskyi B. I. Vybrani pratsi. Kyiv: Naukova dumka, 1969. 439 p.

5. Sertorio L. Thermodynamics of complex systems (An Introduction to Ecophysics). Singapore, New Jersey, London, Hong Kong: World Scientific, 1991. 208 p.

6. Didukh Ya., Lysenko G. Problems of thermodynamic assessment of ecological system structure and arrangement // Visnyk Natsionalnoi akademiyi nauk Ukrainy. 2010. Issue 5. P. 16-27. 
7. Clements F. E. Plant succession. Washington, 1916. 621 p. doi: https://doi.org/10.5962/bhl.title.56234

8. Energy flow and partitioning in selected man-managed and natural ecosystems / Coleman D. C. et. al. // Agro-Ecosystems. 1976. Vol. 3. P. 45-54. doi: https://doi.org/10.1016/0304-3746(76)90099-8

9. Connell J. H., Slatyer R. O. Mechanisms of Succession in Natural Communities and Their Role in Community Stability and Organization // The American Naturalist. 1977. Vol. 111, Issue 982. P. 1119-1144. doi: https://doi.org/10.1086/283241

10. Rifkin J., Howard T. Entropy into the Greenhouse World. New York, Toronto, London, Sydney, Auckland: Bantam Books, 1989. 355 p.

11. Hulst R. Vegetation dynamics or ecosystem dynamics: Dynamic sufficiency in succession theory // Vegetatio. 1980. Vol. 43, Issue 1-2. P. 147-151. doi: https://doi.org/10.1007/bf00121027

12. Khomyak I. V. Phytoindication analisis of preclimax stages of development of ecosystems // Pytannia bioindykatsiyi ta ekolohiyi. 2013. Issue 18. P. 20-29.

13. Shugart H. H. A Theory of Forest Dynamics. The Ecological Implications of Forest Succession Models. New York: Springer, 2003. $278 \mathrm{p}$.

14. Tansley A. G. The Use and Abuse of Vegetational Concepts and Terms // Ecology. 1935. Vol. 16, Issue 3. P. $284-307$. doi: https://doi.org/10.2307/1930070

15. Khomyak I. V. Phytoindication analysis transformation processes in wetlands // Nature Reserves in Ukraine. 2013. Vol. 19, Issue 1. P. 38-42.

16. Utkin A. I. Biologicheskaya produktivnost' lesov (metody izucheniya i rezul'taty). Vol. 1. Moscow: VINITI, 1975.190 p.

17. Khomyak I. V. Phytoindicative characteristic of plant communities transformation of renewable natural vegetation of the Central Polesie // Ekosystemy, yikh optymizatsiya ta okhorona. 2011. Issue 5. P. 58-65.

18. Khomyak I. V. Characteristics of the associations Agrostio-Populetum tremulae and Epilobio-Salicetum capreae of the class Epilobietea angustifolii of the Right Bank Polissy // Ukrainian Botanical Journal. 2016. Vol. 73, Issue 3. P. 239-254. doi: https://doi.org/10.15407/ukrbotj73.03.239

19. Khomiak I. Dynamics of flora in the old-field ecosystem Ukrainian Polissya // ScienceRise: Biological Science. 2018. Issue 1 (10). P. 8-13. doi: https://doi.org/10.15587/2519-8025.2018.121809

20. Rodin L. K., Remezov N. P., Bazilevich N. I. Metodicheskie ukazaniya k izucheniyu dinamiki i biologicheskogo krugovorota v fitocenozah. Leningrad: Nauka, 1967. 145 p.

21. Didukh Ya. P., Pliuta P. H. Fitoindykatsya ekolohichnykh faktoriv. Kyiv: Naukova dumka, 1994. 280 p.

22. Sukcessii i biologicheskiy krugovorot / Titlyanova A. A., Afanas'ev N. A., Naumova N. B. et. al. Novosibirsk: VS "Nauka". Sibirskaya izdatel'skaya firma, 1993. $157 \mathrm{p}$.

23. Mirkin B. M., Naumova L. G., Solomeshch A. I. Sovremennaya nauka o rastitel'nosti. Moscow: Logos, 2001. 264 p.

24. Khomiak I. V. Khomiak D. I. Nova prohrama ekosystemolohichnoho monitorynhu «Simargl» // Materialy nauk.-prakt. konf.: Suchasni problemy ekolohiyi ta heotekhnolohiy. Zhytomyr: Vyd-vo ZhDTU, 2012. P. 76.

Рекомендовано до публікації д-р біол. наук Янович Л. М.

Дата надходження рукопису 08.05.2018

Ivan Khomiak , Associate Professor, Department of Ecology, Nature Using and Human Biology, Zhytomyr Ivan Franko State University, Velyka Berdychivska str., 40, Zhytomyr, Ukraine, 10008

E-mail: ecosystem_lab@ukr.net

Iryna Onyshchuk, Associate Professor, Department of Ecology, Nature Using and Human Biology, Zhytomyr Ivan Franko State University, Velyka Berdychivska str., 40, Zhytomyr, Ukraine, 10008

E-mail: irinashpin@gmail.com

Nataliia Demchuk, Assistant, Department of Ecology, Nature Using and Human Biology, Zhytomyr Ivan Franko State University, Velyka Berdychivska str., 40, Zhytomyr, Ukraine, 10008

E-mail: kadlubovska_n_s@ukr.net 